Original Research

\title{
The Level of Oxytetracycline Uptake in the Presence of Copper Ions and the Physiological Response of Brassica chinensis L.
}

\author{
Ying Li ${ }^{1,2 *}$, Xi Yu' ${ }^{1,2}$, Bei-Bei Bian ${ }^{1,2}$, Shan-Shan Peng ${ }^{1,2}$, Gen Zhang ${ }^{1,3^{*}}$ \\ ${ }^{1}$ Key Laboratory of Biotic Environment and Ecological Safety in Anhui Province, College of Life Sciences, \\ Anhui Normal University, Wuhu, P. R. China \\ ${ }^{2}$ Anhui Provincial Key Laboratories of the Conservation and Exploitation of Biological Resources, \\ College of Life Sciences, Anhui Normal University, Wuhu, P. R. China \\ ${ }^{3}$ Shenzhen GenProMetab Biotechnology Company Limited, Bao'an District, Shenzhen, P. R. China
}

Received: 20 November 2018

Accepted: 28 March 2019

\begin{abstract}
Copper and oxytetracycline (OTC) are two ordinary contaminants in farmlands. In the present study, the effects of oxytetracycline and $\mathrm{Cu}$ on growth, photosynthetic pigments, and antioxidant indices of Brassica chinensis were investigated. The results showed that treatments with OTC promoted growth of seedlings and roots, which were diminished by the addition of $100 \mathrm{mg} / \mathrm{kg} \mathrm{Cu}$. Contents of photosynthetic pigments decreased along with the elevation of OTC concentration. In comparison, their levels increased in the presence of $100 \mathrm{mg} / \mathrm{kg} \mathrm{Cu}$, suggesting that OTC might weaken the toxicity of $\mathrm{Cu}$ on photosynthesis. Moreover, the accumulation of OTC in either plant or soil was relatively lower in treatments with $\mathrm{Cu}$ than those without $\mathrm{Cu}$. Overall, the present results suggested an antagonistic interaction between OTC and $\mathrm{Cu}$ on $B$. chinensis.
\end{abstract}

Keywords: antibiotics, antioxidant, copper, plant growth, photosynthesis

\section{Introduction}

Trace metals and antibiotics are two groups of ordinary contaminants. Both of them reveal high risk to environments. With the rapid development of intensive livestock and poultry farming, trace metals and antibiotics were largely accumulated in breeding wastewater due to common use of metals and veterinary medicines as animal food additives [1]. For instance, the metals copper, zinc, lead, cadmium, nickel, and chromium and several antibiotics were detectable in large-scale pig farms [2]. This wastewater was generally used to irrigate agricultural lands, further leading to concomitant input of metals and antibiotics [3]. Co-contamination of antibiotics and metals would pose considerable toxicological risks to soils and crops [4]. 
$\mathrm{Cu}$ is an essential microelement to plants, but it is toxic to plants at high concentrations. For instance, $\mathrm{Cu}$ displayed harmful effects to Brassica chinensis L. with $\mathrm{EC}_{50}$ of total $\mathrm{Cu}$ varying from 0.06 to $0.72 \mu \mathrm{M}$ and $\mathrm{EC}_{50}$ of free $\mathrm{Cu}^{2+}$ from 0.06 to $0.19 \mu \mathrm{M}$ [5]. Treatments with a high level of $\mathrm{Cu}$ severely inhibited growth (shoot length, number of roots and leaves, and fresh weight) of Solanum nigrum and Solanum lycopersicum [6]. Oxytetracycline (OTC) is widely used to prevent diseases in livestock. A high level of OTC was detected in soil [7], water [8], animals [9,10] and plants [11,12]. Although OTC pollution in soil at concentration of $30 \mathrm{mg} / \mathrm{kg}$ showed no significant effects on seed germination and plant growth of Chinese cabbage, pollution at the levels of 10 and $30 \mathrm{mg} / \mathrm{kg}$ significantly affected root elongation, shoot length, and biomass of seedling [13]. These reports displayed toxicity and environmental behavior of $\mathrm{Cu}$ or OTC to organisms. However, they only investigated effects of single pollutants. Combined effects of $\mathrm{Cu}$ and OTC on crops are still rarely understood.

Brassica chinensis L. is a common crop in China and also a model plant for toxic assessments. In the present study, B. chinensis was employed as the study object and interactive effects of $\mathrm{Cu}$ and OTC on growth and physiological properties of $B$. chinensis and chemical properties of soil were investigated. Meanwhile, the accumulation of $\mathrm{Cu}$ and OTC in B. chinensis and soil was also determined. These results together would contribute to further understanding of toxicity and safety assessments of combined pollution of $\mathrm{Cu}$ and OTC.

\section{Experimental}

\section{Materials}

For cultivation of $B$. chinensis, surface soil $(0-20 \mathrm{~cm})$ was collected from an unpolluted area on a hill located at the Zheshan campus of Anhui Normal University $\left(31^{\circ} 20^{\prime} 9.37^{\prime \prime} \mathrm{N}, \quad 118^{\circ} 22^{\prime} 9.14^{\prime \prime} \mathrm{E}\right)$ and then mixed with commercial nutrient soil (Biaoyoumei Ecological Engineering Company, Nanjing, China) at a ratio of 3:1. The basic physiochemical parameters of these artificial soils were as follows: $\mathrm{pH}=7.24$, content of organic matters $=12.5 \mathrm{~g} / \mathrm{kg}$, content of available $\mathrm{N}=0.63 \mathrm{~g} / \mathrm{kg}$, content of available $\mathrm{P}=0.37 \mathrm{~g} / \mathrm{kg}$, content of available $\mathrm{K}=10.06 \mathrm{~g} / \mathrm{kg}$, and content of total $\mathrm{Cu}=25.46 \mathrm{mg} / \mathrm{kg}$. No fertilization was performed during the whole experiment. Seeds of B. chinensis L. were purchased from Anhui Huahe Seeds Company (Hefei, China). OTC (purity 98\%) was purchased from Anhui Tiangen Biochemical Science and Technology Company (Hefei, China). $\mathrm{CuSO}_{4} \cdot 5 \mathrm{H}_{2} \mathrm{O}$ (analytical grade) was used as the source of copper.

\section{Sample Treatments}

As previously reported, treatments with $20-50 \mathrm{mg} / \mathrm{kg}$ OTC significantly inhibited germination of $B$. chinensis and treatments with $5-30 \mathrm{mg} / \mathrm{kg}$ OTC significantly stimulated oxidative effects on $B$. chinensis seedlings [14]. Based on these results, three concentrations of OTC $(5,10$ and $20 \mathrm{mg} / \mathrm{kg})$ were set in the present study. Wahida et al. [15] showed that treatment with up to $60 \mathrm{mg} / \mathrm{kg} \mathrm{Cu}$ in Histosol soil significantly suppressed plant height of Brassica rapa var. parachinensis. Thus, concentration of total $\mathrm{Cu}$ was set at $100 \mathrm{mg} / \mathrm{kg}$ in soil in the present study.

Before commencing the experiments, OTC with or without $100 \mathrm{mg} / \mathrm{kg} \mathrm{Cu}$ was added in soil and thoroughly mixed. Treatment without OTC or $\mathrm{Cu}$ was also prepared as control. Each treatment was repeated three times.

In each treatment, 100 seeds of $B$. chinensis were sown in each pot $(47 \mathrm{~cm} \times 23 \mathrm{~cm} \times 18 \mathrm{~cm}$, volume of soil $=13.5 \mathrm{~L}$ ) at the end of September, 2017 and then cultured in the greenhouse. After one week, 80 plants were retained in each pot. During the culture, water content in soil was maintained at $60-70 \%$ of maximum water-holding capacity by irrigating distilled water. Light cycle was $14 \mathrm{~h}$ : $10 \mathrm{~h}$ (day: night). During day time, light intensity was approximately 80-100 klux and temperature was $20-25^{\circ} \mathrm{C}$. During night, temperature ranged from $10^{\circ} \mathrm{C}$ to $12^{\circ} \mathrm{C}$. During the whole experiment, air humidity was approximately $70 \%$. After two months, all plants were collected, washed with distilled water and dried using filter paper.

\section{Determining Growth Indices}

From each treatment, 10 plants were randomly selected. Plant height and root length were measured using a ruler. Aboveground (AGP) and underground (UGP) parts were separated and weighed using an analytical balance.

\section{Determining Content of Photosynthetic Pigments}

Contents of photosynthetic pigments were determined according to Zhang and Qu [16]. For each treatment, $0.5 \mathrm{~g}$ of fresh leaves were completely homogenized in $2 \mathrm{~mL}$ of acetone with $0.5 \mathrm{~g}$ of quartz sands, and then total volume was adjusted to $20 \mathrm{~mL}$ by adding $80 \%$ acetone. The mixture was filtered using filter paper. Next, absorbance at $663 \mathrm{~nm}, 645 \mathrm{~nm}$ and $440 \mathrm{~nm}$ was measured to calculate content of chlorophyll a (Chl-a), b (Chl-b) and carotenoids (Chl-cx).

\section{Determining Antioxidant Indices}

Activity of superoxide dismutase (SOD), catalase (CAT) and peroxidase (POD) and level of 
malondialdehyde (MDA) was measured as described by Zhang, Huang, and Chen [17], Proinoke [18], Zhang and $\mathrm{Qu}$ [16], respectively. One unit of SOD activity was defined as the amount of enzyme required for 1 gram of tissue in $1 \mathrm{ml}$ of reaction mixture to achieve SOD inhibition rate of $50 \%$. One unit of POD activity was defined as a change of absorbance at $420 \mathrm{~nm}$ for 0.01 . Decrease in absorbance at $240 \mathrm{~nm}$ for 0.01 represented one unit of CAT. Each assay was repeated three times.

\section{Determining Soil Parameters}

Soil $\mathrm{pH}$ value was determined by mixing $10 \mathrm{~g}$ of soil with $25 \mathrm{~mL}$ of $\mathrm{CO}_{2}$-free $\mathrm{H}_{2} \mathrm{O}$ in 50 -mL glass beaker for $1 \mathrm{~min}$. After standing for $30 \mathrm{~min}, \mathrm{pH}$ value of solution was measured using a $\mathrm{pH}$ meter.

Content of organic $\mathrm{N}$ in soil was determined using the alkali hydrolysis method. Air-dried soil was sieved using a $1 \mathrm{~mm}$ pore-sized sieve. Next, $2 \mathrm{~g}$ of soil was mixed with $1 \mathrm{~g}$ of $\mathrm{FeSO}_{4}$ and then placed in the outer block of nitrogen diffusion dish. In the inner block of dish, $2 \mathrm{~mL}$ of $2 \% \mathrm{H}_{3} \mathrm{BO}_{3}$ solution and 1 drop of indicator were added. After $10 \mathrm{~mL}$ of $1.6 \mathrm{~mol} / \mathrm{L} \mathrm{NaOH}$ solution was added to soil, the dish was immediately covered by glass slip and completely sealed using glue. When soil was thoroughly infiltrated by $\mathrm{NaOH}$ solution, the whole apparatus was kept at $40^{\circ} \mathrm{C}$ for 24 hours. Next, the amount of ammonia absorbed by $\mathrm{H}_{3} \mathrm{BO}_{3}$ was determined by titration using $0.01 \mathrm{~mol} / \mathrm{L} \mathrm{HCl}$ solution. The titration was ended when the color of the solution changed from blue to light red.

To determine content of organic matters [19], $0.3 \mathrm{~g}$ of soil was mixed with $10 \mathrm{~mL}$ of $0.4 \mathrm{~mol} / \mathrm{L}$ $\mathrm{K}_{2} \mathrm{Cr}_{2} \mathrm{O}_{7}$ solution in glass test tubes. Tubes were heated at 170 to $180^{\circ} \mathrm{C}$ for $5 \mathrm{~min}$ and then totally transferred to a $150-\mathrm{mL}$ flask. Content of organic matter was titrated using $0.2 \mathrm{~mol} / \mathrm{L} \mathrm{FeSO}_{4}$ solution. 1,10-phenanthrolinemonohydrate was used as the indicator and the alteration of color to brick-red was considered as the endpoint.

\section{Determining $\mathrm{Cu}$ Contents in Plants and Soil}

Plants were washed carefully using distilled water and then completely dried at $80^{\circ} \mathrm{C}$. Afterward, plants were crushed and $1 \mathrm{~g}$ of sample was digested in $5 \mathrm{~mL}$ of acid mixture $\left(\mathrm{HNO}_{3}: \mathrm{HClO}_{4}: \mathrm{H}_{2} \mathrm{SO}_{4}=8: 1: 1\right)$. After evaporation of acid, samples were dissolved in $7 \% \mathrm{HNO}_{3}$ solution and then diluted to $50 \mathrm{~mL}$ using distilled $\mathrm{H}_{2} \mathrm{O}$. $\mathrm{Cu}$ content was determined using an atomic absorption spectrometer [20].

To determine content of available $\mathrm{Cu}$, rhizosphere soil (approximately $2 \mathrm{~mm}$ to root surface) was collected, completely dried and then crushed into powders. After being sieved through an 80-mesh sieve, approximately $5 \mathrm{~g}$ of soil was weighed and placed in a $100-\mathrm{mL}$ glass flask. After $20 \mathrm{~mL}$ of $0.1 \mathrm{~mol} / \mathrm{L} \mathrm{HCl}$ solution was added, the flask was shaken at $180 \mathrm{rpm}$ for $30 \mathrm{~min}$ to extract available $\mathrm{Cu}$. The mixture was filtered through filter paper and content of $\mathrm{Cu}$ in solution (representing available $\mathrm{Cu}$ ) was determined using an atomic absorption spectrometer [20].

\section{Determining OTC Contents in Plants}

Determining OTC contents followed the Chinese Standard GB/T 22259 with slight modification [21]. Briefly, plant samples were ground into powders using liquid nitrogen. $6 \mathrm{~g}$ of each sample was extracted in $10 \mathrm{~mL}$ of extraction solution (25\% methanol and $0.3 \mathrm{~mol} / \mathrm{L} \mathrm{HCl}$ ) by sonication for $30 \mathrm{~min}$. After centrifuging at 4,000 rpm for $40 \mathrm{~min}$, supernatant was collected. This process was repeated 3 times and all supernatants were pooled and purified using Oassis HLB SPE columns and eluted using $15 \mathrm{~mL}$ of ethyl acetate. After being dried using a speedvac, the extract was dissolved in $1 \mathrm{~mL}$ of methanol.

For high-performance liquid chromatography (HPLC) analysis, $100 \mu \mathrm{L}$ of sample solution was injected into an LC-20A HPLC (Shimadzu, Japan) equipped with an Ultimate XB-C $\mathrm{C}_{18}$ column $(150 \mathrm{~mm} \times 4.6 \mathrm{~mm} \times$ $5 \mu \mathrm{m})$. The HPLC process was as follows: concentration of acetonitrile (containing 0.1\% TFA) increased from 5\% to $95 \%$ within $60 \mathrm{~min}$ and absorbance at $353 \mathrm{~nm}$ was monitored. Standard curve was prepared by injecting $100 \mu \mathrm{L}$ of $100,50,20,10$ and $20 \mathrm{mg} / \mathrm{L}$ standard OTC solution to HPLC.

\section{Data Analyses}

The statistical analyses were performed using SPSS 19.0. The homogeneity for variance was checked first. One-way variance analysis was performed to check the effects of OTC on all tested indicators, followed by Student-Newman-Keuls tests (SNK). Students' t-test was performed to compare the results between treatment with and without $\mathrm{Cu} . \mathrm{P}<0.05$ was considered a significant statistical difference.

\section{Results}

\section{Effects of $\mathrm{Cu}$ and OTC on Growth Indices}

In the absence of copper, OTC significantly affected plant height and root length, but not fresh weight of total plant, UGP and AGP. Compared with the control, treatments with 5 and $10 \mathrm{mg} / \mathrm{kg}$ OTC significantly increased plant height. Treatment with $10 \mathrm{mg} / \mathrm{kg}$ OTC significantly affected root length. However, no significant differences in both plant height and root length were detected in treatment with $20 \mathrm{mg} / \mathrm{kg}$ OTC (Table 1).

In the presence of $100 \mathrm{mg} / \mathrm{kg} \mathrm{Cu}$, treatment with OTC significantly affected root length but not plant height. Compared with the control, treatment with $10 \mathrm{mg} / \mathrm{kg}$ OTC significantly reduced root length. 
Table 1. Growth indices of Brassica chinensis L. in treatments with $\mathrm{Cu}$ and OTC (mean $\pm \mathrm{SE}$ ).

\begin{tabular}{|c|c|c|c|c|c|}
\hline \multirow{2}{*}{$\begin{array}{c}\text { OTC } \\
(\mathrm{mg} / \mathrm{kg})\end{array}$} & \multirow{2}{*}{$\begin{array}{l}\text { Plant height } \\
\quad(\mathrm{cm})\end{array}$} & \multirow{2}{*}{$\begin{array}{l}\text { Root length } \\
\quad(\mathrm{cm})\end{array}$} & \multicolumn{3}{|c|}{ Fresh weight (g/plant) } \\
\hline & & & Total plant & UGP & AGP \\
\hline \multicolumn{6}{|c|}{$\mathrm{Cu}$ concentration: $0 \mathrm{mg} / \mathrm{kg}$} \\
\hline 0 & $13.74 \pm 1.08^{\mathrm{a}}$ & $1.90 \pm 0.27^{\mathrm{a}}$ & $0.28 \pm 0.03^{*}$ & $0.01 \pm 0.002$ & $0.27 \pm 0.03^{*}$ \\
\hline 5 & $18.55 \pm 0.93^{\mathrm{b}}$ & $2.25 \pm 0.2^{\mathrm{a}}$ & $0.47 \pm 0.06^{*}$ & $0.01 \pm 0.001$ & $0.41 \pm 0.05^{*}$ \\
\hline 10 & $19.18 \pm 1.56^{\mathrm{b}}$ & $3.31 \pm 0.51^{\mathrm{b}}$ & $0.49 \pm 0.09^{*}$ & $0.01 \pm 0.003$ & $0.48 \pm 0.09^{*}$ \\
\hline 20 & $16.61 \pm 0.94$ & $2.33 \pm 0.34$ & $0.43 \pm 0.05^{*}$ & $0.02 \pm 0.003$ & $0.43 \pm 0.06^{*}$ \\
\hline \multicolumn{6}{|c|}{$\mathrm{Cu}$ concentration: $100 \mathrm{mg} / \mathrm{kg}$} \\
\hline 0 & $16.69 \pm 0.59$ & $3.12 \pm 0.38^{\mathrm{a}}$ & $0.59 \pm 0.10$ & $0.02 \pm 0.003$ & $0.53 \pm 0.10$ \\
\hline 5 & $17.34 \pm 0.76$ & $3.85 \pm 0.35^{\mathrm{a}}$ & $0.39 \pm 0.04$ & $0.02 \pm 0.004$ & $0.36 \pm 0.04$ \\
\hline 10 & $17.34 \pm 0.56$ & $2.04 \pm 0.23^{b}$ & $0.45 \pm 0.05$ & $0.02 \pm 0.003$ & $0.43 \pm 0.05$ \\
\hline 20 & $17.18 \pm 0.72$ & $2.82 \pm 0.36^{\mathrm{a}}$ & $0.43 \pm 0.06$ & $0.01 \pm 0.002$ & $0.42 \pm 0.06$ \\
\hline
\end{tabular}

UPG: under-ground part; AGP: above-ground part; the different letters represent significant differences within the same column

*significantly different between treatments with the same concentration of OTC in the presence and absence of $\mathrm{Cu}(\mathrm{n}=30)$

Treatments with 5 and $20 \mathrm{mg} / \mathrm{kg}$ OTC showed no effects on root length (Table 1).

In the absence of OTC, treatment with $100 \mathrm{mg} / \mathrm{kg}$ $\mathrm{Cu}$ significantly increased fresh weight of total plant and AGP compared with the control. At the same concentration of OTC $(5-20 \mathrm{mg} / \mathrm{kg})$, all treatments with $100 \mathrm{mg} / \mathrm{kg} \mathrm{Cu}$ significantly reduced fresh weight of total plant and AGP than those without $\mathrm{Cu}$.

\section{Effects of Copper and OTC on Photosynthetic Pigments}

Without the addition of $\mathrm{Cu}$, treatments with $5-20 \mathrm{mg} / \mathrm{kg}$ OTC significantly reduced contents of Chl-a, Chl-b and Chl-cx. In comparison, when $100 \mathrm{mg} / \mathrm{kg} \mathrm{Cu}$ was added, treatment with $20 \mathrm{mg} / \mathrm{kg}$ OTC increased the level of Chl-a, and treatments with 10 and $20 \mathrm{mg} / \mathrm{kg}$ OTC elevated contents of Chl-b and Chl-cx (Fig. 1).

a) Without $\mathrm{Cu}$

b) With $100 \mathrm{mg} / \mathrm{kg} \mathrm{Cu}$

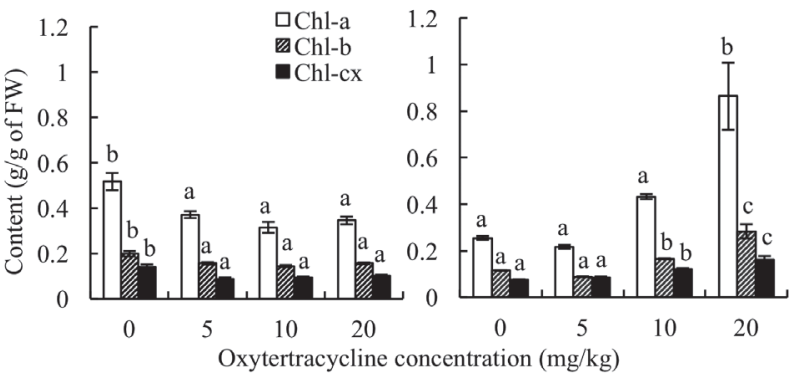

Fig. 1. Effects on $\mathrm{Cu}$ and OTC on contents of photosynthetic pigments in $B$. chinensis L (mean $\pm \mathrm{SE})$. Chl-a: chlorophyll a; Chl-b: chlorophyll b; Chl-cx: carotenoid; the different letters represent significant differences within the same column $(n=3)$.

\section{Effects of $\mathrm{Cu}$ and OTC on Antioxidant Activities}

Regardless of $\mathrm{Cu}$, treatments with OTC significantly affected the level of MDA and activities of CAT and POD in $B$. chinensis, but did not affect SOD activity. In comparison to the control, treatments with $10-20 \mathrm{mg} / \mathrm{kg}$ OTC significantly elevated activities of CAT and POD. In the absence of $\mathrm{Cu}$, treatment with $10 \mathrm{mg} / \mathrm{kg}$ OTC significantly increased the level of MDA, but treatments with $5-20 \mathrm{mg} / \mathrm{kg}$ OTC did not affect activity of POD. In the presence of $100 \mathrm{mg} / \mathrm{kg} \mathrm{Cu}$, treatment with $20 \mathrm{mg} / \mathrm{kg}$ OTC enhanced the activity of POD, but no changes were observed in the level of MDA at all OTC concentrations (Table 2).

Table 2. Effects of $\mathrm{Cu}$ and OTC on antioxidant indicators in $B$. chinensis L. (mean $\pm \mathrm{SE})$.

\begin{tabular}{|c|c|c|c|c|}
\hline $\begin{array}{c}\text { OTC } \\
(\mathrm{mg} / \mathrm{kg})\end{array}$ & $\begin{array}{c}\text { MDA } \\
(\mathrm{nmol} / \mathrm{g})\end{array}$ & $\begin{array}{c}\text { CAT } \\
(\mathrm{U} / \mathrm{g} / \mathrm{min})\end{array}$ & $\begin{array}{c}\text { POD } \\
(\mathrm{U} / \mathrm{g} / \mathrm{min})\end{array}$ & $\begin{array}{c}\text { SOD } \\
(\mathrm{U} / \mathrm{g} / \mathrm{min})\end{array}$ \\
\hline \multicolumn{5}{|c|}{ Cu concentration: $0 \mathrm{mg} / \mathrm{kg}$} \\
\hline 0 & $1.3 \pm 0.1^{\text {ac }}$ & $82 \pm 5^{\mathrm{a}}$ & $7440 \pm 840$ & $0.34 \pm 0.03$ \\
\hline 5 & $1.4 \pm 0.2^{\mathrm{ab}}$ & $92 \pm 8^{\mathrm{a}}$ & $5232 \pm 579^{\mathrm{a}}$ & $0.38 \pm 0.07$ \\
\hline 10 & $1.8 \pm 0.1^{\mathrm{b}}$ & $160 \pm 15^{\mathrm{b}}$ & $8295 \pm 587^{\mathrm{b}}$ & $0.44 \pm 0.02$ \\
\hline 20 & $0.9 \pm 0.2^{\mathrm{c}}$ & $747 \pm 4^{\mathrm{c}}$ & $5994 \pm 680^{\mathrm{a}}$ & $0.44 \pm 0.02$ \\
\hline \multicolumn{5}{|c|}{$\mathrm{Cu}^{\mathrm{c}} \mathrm{concentration:} 100 \mathrm{mg} / \mathrm{kg}$} \\
\hline 0 & $1.0 \pm 0.2$ & $48 \pm 0^{\mathrm{a}}$ & $4221 \pm 558^{\mathrm{a}}$ & $0.34 \pm 0.10$ \\
\hline 5 & $1.5 \pm 0.1^{\mathrm{a}}$ & $67 \pm 0^{\mathrm{a}}$ & $6025 \pm 542^{\mathrm{a}}$ & $0.45 \pm 0.03$ \\
\hline 10 & $1.1 \pm 0.2$ & $2016 \pm 13^{\mathrm{b}}$ & $5779 \pm 603^{\mathrm{a}}$ & $0.42 \pm 0.04$ \\
\hline 20 & $0.8 \pm 0.1^{\mathrm{b}}$ & $1212 \pm 6^{\mathrm{c}}$ & $9547 \pm 852^{\mathrm{b}}$ & $0.44 \pm 0.03$ \\
\hline
\end{tabular}

Different letters represent significant differences within the same column $(\mathrm{n}=3)$. 
Table 3. Chemical properties of rhizosphere soil of B. chinensis treated with $\mathrm{Cu}$ and OTC (mean $\pm \mathrm{SE})$.

\begin{tabular}{|c|c|c|c|}
\hline $\begin{array}{c}\text { OTC } \\
\left(\mathrm{mg} \cdot \mathrm{kg}^{-1}\right)\end{array}$ & $\begin{array}{c}\text { Organic matter } \\
(\mathrm{g} / \mathrm{kg})\end{array}$ & $\begin{array}{c}\mathrm{N} \\
(\mathrm{g} / \mathrm{kg})\end{array}$ & $\mathrm{pH}$ \\
\hline \multicolumn{4}{|c|}{ Cu concentration: $0 \mathrm{mg} / \mathrm{kg}$} \\
\hline 0 & $6.8 \pm 0.1^{\mathrm{a}}$ & $0.6 \pm 0.0^{\mathrm{ab}}$ & $7.4 \pm 0.1$ \\
\hline 5 & $7.1 \pm 0.1^{\mathrm{a}}$ & $1.4 \pm 0.0^{\mathrm{c}}$ & $7.6 \pm 0.1$ \\
\hline 10 & $6.3 \pm 0.3^{\mathrm{b}}$ & $0.5 \pm 0.1^{\mathrm{a}}$ & $7.6 \pm 0.0$ \\
\hline 20 & $6.1 \pm 0.2^{\mathrm{b}}$ & $0.7 \pm 0.0^{\mathrm{b}}$ & $7.7 \pm 0.1$ \\
\hline \multicolumn{5}{|c|}{ Cu concentration: $100 \mathrm{mg} / \mathrm{kg}$} \\
\hline 0 & $5.3 \pm 0.2^{\mathrm{a}}$ & $0.4 \pm 0.0^{\mathrm{a}}$ & $7.7 \pm 0.1^{\mathrm{a}}$ \\
\hline 5 & $6.8 \pm 0.1^{\mathrm{b}}$ & $0.6 \pm 0.0^{\mathrm{b}}$ & $7.6 \pm 0.1^{\mathrm{a}}$ \\
\hline 10 & $5.5 \pm 0.1^{\mathrm{ca}}$ & $0.8 \pm 0.1^{\mathrm{c}}$ & $7.0 \pm 0.0^{\mathrm{b}}$ \\
\hline 20 & $5.8 \pm 0.1^{\mathrm{dc}}$ & $0.4 \pm 0.0^{\mathrm{ad}}$ & $7.0 \pm 0.1^{\mathrm{b}}$ \\
\hline
\end{tabular}

Different letters represent significant differences within the same column $(\mathrm{n}=3)$.

\section{Effects of $\mathrm{Cu}$ and OTC on Soil Parameters}

Without extra $\mathrm{Cu}$, treatments with $10-20 \mathrm{mg} / \mathrm{kg}$ OTC significantly decreased content of organic matters in rhizosphere soil in comparison to the control. Treatments with 5 and $20 \mathrm{mg} / \mathrm{kg}$ OTC significantly increased $\mathrm{N}$ content, but no effects of OTC were observed on $\mathrm{pH}$ value of soil (Table 3 ).

With the addition of $100 \mathrm{mg} / \mathrm{kg} \mathrm{Cu}$, treatments with 5 and $20 \mathrm{mg} / \mathrm{kg}$ OTC increased content of organic matters, treatments with 5 and $10 \mathrm{mg} / \mathrm{kg}$ OTC increased content of $\mathrm{N}$, and treatments with $10-20 \mathrm{mg} / \mathrm{kg}$ OTC decreased $\mathrm{pH}$ value of soil compared with the control (Table 3).

\section{$\mathrm{Cu}$ Contents in Plants and Soil}

No matter whether extra $\mathrm{Cu}$ was added, similar patterns were observed for content of total $\mathrm{Cu}$ in plants, total $\mathrm{Cu}$ and available $\mathrm{Cu}$ in soil, along with increasing concentrations of OTC. Treatments with OTC decreased levels of total $\mathrm{Cu}$ but increased available $\mathrm{Cu}$ in soil.

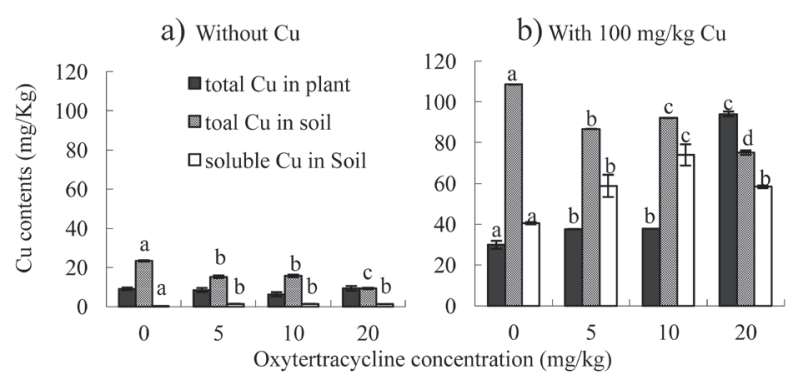

Fig. 2. $\mathrm{Cu}$ content in B. chinensis and soil in treatments with $\mathrm{Cu}$ and OTC (mean $\pm \mathrm{SE})$.
Without extra $\mathrm{Cu}$, levels of total $\mathrm{Cu}$ in plants did not change in response to OTC. However, $\mathrm{Cu}$ content in plants increased gradually with increasing levels of OTC when extra $\mathrm{Cu}$ was added (Fig. 2).

\section{OTC Contents in Plants}

Without the addition of extra $\mathrm{Cu}$, relatively higher levels of OTC were detected in plants compared with those in soil. When extra $\mathrm{Cu}$ was added, OTC was not detected in both soil and plants (Table 4).

\section{Discussion}

Previously, Tian et al. [22] showed that treatments with $25-50 \mathrm{mg} / \mathrm{kg}$ OTC promoted germination and seedling growth of cucumber. Treatment with $1 \mathrm{mg} / \mathrm{L}$ OTC inhibited root growth of lettuce, and treatments with OTC higher than $5 \mathrm{mg} / \mathrm{L}$ inhibited leaf growth. In the present study, similar results were observed. Treatment with $5 \mathrm{mg} / \mathrm{kg}$ OTC increased plant height, and treatment with $10 \mathrm{mg} / \mathrm{kg}$ increased root length, but in treatment with $20 \mathrm{mg} / \mathrm{kg}$ OTC, no significant differences in plant height and root length were observed. These results suggested that treatments with OTC at low concentrations might facilitate growth of B. chinensis, but treatments with OTC at high concentrations might be harmful to its growth, which is consistent with the reports of Tian et al. [22] and Cui [23].

High concentrations of $\mathrm{Cu}$ are known to activate oxidative damage and alter cell-membrane properties by lipid peroxidation, thereby demonstrating inhibitory effects on enzymes involved in chlorophyll production [24]. Moreover, exposure to $\mathrm{Cu}$ could affect mineral uptake in plants and decrease contents of numerous minerals in leaves, inhibiting synthesis of photosynthetic pigments [25]. In the present study, similar results were observed. Treatment with $100 \mathrm{mg} / \mathrm{kg} \mathrm{Cu}$ significantly decreased levels of Chl-a, Chl-b and Chl-cx, in comparison to the control (no $\mathrm{Cu}$ and no OTC). Regarding underlying mechanisms, oxidative effects of $\mathrm{Cu}$ on enzymes might not be the reason, since activities of antioxidant enzymes and MDA level were not significantly higher in treatment with $\mathrm{Cu}$ than the control (Table 2). Whether or not changes of mineral contents were involved in this process should be further investigated.

Chen et al. [26] revealed that exposure to $10-200 \mathrm{mg} / \mathrm{kg}$ OTC diminished photosynthetic capacity of rape by altering energy distribution in photosynthetic electron transport chain. Similarly, treatments with OTC higher than $25 \mathrm{mg} / \mathrm{kg}$ reduced the photosynthetic rate of radish plants [27]. In the present study, treatments with $5-20 \mathrm{mg} / \mathrm{kg}$ OTC significantly decreased contents of Chl-a, Chl-b and Chl-cx, which is consistent with previous findings $[26,27]$. When $\mathrm{Cu}$ was added, levels of photosynthetic pigments increased with elevation of OTC concentration, suggesting interactive effects 
Table 4. OTC content in soil and B. chinensis after experiments..

\begin{tabular}{|c|c|c|}
\hline \multirow{3}{*}{$\begin{array}{c}\text { OTC treatment } \\
(\mathrm{mg} / \mathrm{kg})\end{array}$} & Soil & PTC content $(\mathrm{mg} / \mathrm{kg})$ \\
\cline { 2 - 3 } Cu treatment: $0 \mathrm{mg} / \mathrm{kg}$ \\
\hline 0 & - & - \\
\hline 5 & 3.72 & 27.37 \\
\hline 10 & 3.33 & 87.67 \\
\hline 20 & 7.73 & 13.66 \\
\hline & Cu treatment: $100 \mathrm{mg} / \mathrm{kg}$ & \\
\hline 0 & - & - \\
\hline 5 & - & - \\
\hline 10 & - & - \\
\hline 20 & - & - \\
\hline
\end{tabular}

“-”: not detected

between $\mathrm{Cu}$ and OTC. OTC could form a complex with $\mathrm{Cu}$ [23], probably decreasing concentration of available $\mathrm{Cu}$ and OTC in plants (Fig. 2 and Table 4) and subsequently weakening the harmful effects of $\mathrm{Cu}$ on synthesis of pigments. However, more investigations are required to clarify this viewpoint.

Changes of MDA, CAT, POD and SOD in the presence/absence of extra $\mathrm{Cu}$ were rather complicated. Treatment with $20 \mathrm{mg} / \mathrm{kg}$ OTC decreased MDA level, but treatment with $20 \mathrm{mg} / \mathrm{kg}$ OTC and $100 \mathrm{mg} / \mathrm{kg} \mathrm{Cu}$ showed no effects on MDA, demonstrating antagonism between OTC and $\mathrm{Cu}$. The tendency of CAT activity with increasing level of OTC was similar between treatments with and without extra $\mathrm{Cu}$, suggesting no interactions between them. In the absence of $\mathrm{Cu}$, no significant effects were detected between treatments with OTC and the control, but a significant difference was observed between treatment with $20 \mathrm{mg} / \mathrm{kg}$ OTC and the control in the presence of $\mathrm{Cu}$, indicating synergism between $\mathrm{Cu}$ and OTC. Moreover, no changes were detected in SOD activity in all treatments. These results were hard to explain, but implied a complicated mechanism underlying the interactive effects of $\mathrm{Cu}$ and OTC on the antioxidant process in B. chinensis.

Contents of organic matters and $\mathrm{N}$ in soil were mainly influenced by root and microorganism activities. Roots could secrete organic acids to soil [28] and autotrophic bacteria could transform inorganic chemicals to organic matters. These two processes should increase content of organic matters in rhizosphere soils. In comparison, methane generation by microorganisms would decrease content of organic matters due to biogas production [29]. In the present study, regardless of $\mathrm{Cu}$, the level of organic matter and $\mathrm{N}$ showed a similar tendency, increasing at low concentrations of OTC but decreasing afterward. In treatment with $5 \mathrm{mg} / \mathrm{kg}$ OTC, although no significant differences in root length were observed from the control, the average values of root length were higher than those in the control, suggesting that more organic matters might be secreted by roots into soils. Besides, treatments with OTC might decrease biogas production due to inhibition of methane generation by microorganisms [29], which could accumulate more organic matters in soil. This hypothesis required more evidence to support. When concentration of OTC further increased, only treatment with $10 \mathrm{mg} / \mathrm{kg}$ OTC and $100 \mathrm{mg} / \mathrm{kg} \mathrm{Cu}$ significantly reduced root length. These results suggested that inhibition of root growth might contribute to decreased organic content in soil, but it must not be the sole reason. Alternatively, the activity of microorganisms might be severely inhibited by OTC and less organic matters could be generated by microorganisms.

Certain metals could play a "bridge" role in promoting the removal of antibiotics in flocculation. For example, $\mathrm{Cu}^{2+}$ improved the removal of coexisted antibiotic molecules [30] and could accelerate photolysis of OTC [23]. In the present study, the residual level of OTC was relatively lower in plants and soil when $\mathrm{Cu}$ was added than those without $\mathrm{Cu}$, probably also due to the promotive effects of $\mathrm{Cu}$ on OTC degradation.

When $100 \mathrm{mg} / \mathrm{kg} \mathrm{Cu}$ was added, content of total $\mathrm{Cu}$ in soil decreased, but content of available $\mathrm{Cu}$ in soil and content of total $\mathrm{Cu}$ in plant increased along with elevated level of OTC, suggesting that treatment with OTC might enhance bioavailability of $\mathrm{Cu}$ in soil and promote absorption of $\mathrm{Cu}$ by plants. These results might be due a systematic ecological process. As previously reported, dissolved organic matters (DOC) significantly bind heavy metals such as $\mathrm{Cu}[31,32]$. This kind of $\mathrm{Cu}-\mathrm{DOC}$ complex could enhance mobility and bioavailability of $\mathrm{Cu}$ [33]. In the present study, contents of organic matters and $\mathrm{N}$ in soil increased first and then decreased with elevating concentrations of OTC, probably resulting in the similar tendency of changes in available $\mathrm{Cu}$ content in soil. The higher level of available $\mathrm{Cu}$ content in soil, the more $\mathrm{Cu}$ absorbed by plants, and the lower the total $\mathrm{Cu}$ retained in soil.

\section{Conclusions}

Treatments with OTC promoted growth of seedlings and roots in B. chinensis, and these promotive effects could be diminished by the addition of $100 \mathrm{mg} /$ $\mathrm{kg} \mathrm{Cu}$. Treatment with OTC decreased contents of photosynthetic pigments, but their levels increased in the presence of $100 \mathrm{mg} / \mathrm{kg} \mathrm{Cu}$, suggesting that OTC might weaken toxicity of $\mathrm{Cu}$ on photosynthesis. Moreover, the presence of $\mathrm{Cu}$ reduced the accumulation of OTC in either plant or soil. Overall, OTC might antagonistically interact with $\mathrm{Cu}$ in $B$. chinensis. 


\section{Funding}

This work was supported by the Natural Science Foundation of Educational Committee of Anhui Province (KJ2012A132).

\section{Acknowledgements}

We thank Shenzhen Nobel Science and Technology Service Company for comments and English corrections on the present manuscript. This study was supplied by the Collaborative Innovation Center of Recovery and Reconstruction of Degraded Ecosystems in Wanjiang City Belt, Anhui Province.

\section{Conflict of Interest}

The authors declare no conflict of interest.

\section{References}

1. XIN L.U., LUO J., GAO Y., YAN S.H., ZHANG Z.H. A review in ecotoxic effect of antibiotics and heavy metals co-contamination in livestock and poultry breeding wastewater and its remediation. [In China] Jiangsu Journal of Agricultural Science. 139 (1), 546, 2014.

2. LIU R., CHEN L., WANG G., YE Z. On the Pollution with Antibiotics, Heavy Metals and Conventional Indicators in Digested Wastewater from Large-scale Pig Farms in Jiaxing City, China. Environ Eng Manag J. 15 (10), 2253, 2016.

3. TAMTAM F., VAN OORT F., LE BOT B., DINH T., MOMPELAT S., CHEVREUIL M., LAMY I., THIRY M. Assessing the fate of antibiotic contaminants in metal contaminated soils four years after cessation of long-term waste water irrigation. Sci Total Environ. 409 (3), 540, 2011.

4. LIU Y., LIU H., WU L., XU M., CUI J., GAO W., CHENG C., YUE X. Co-contamination of heavy metals and antibiotics in soils under husbandry wastewater irrigation in Guiyang City. Acta Scie Circum. 37 (3), 1074, 2017.

5. WANG X.D., ZHENG Y.L., HUA L. Effects of Ca, $\mathrm{Mg}, \mathrm{K}, \mathrm{Na}$, and $\mathrm{pH}$ on copper toxicity to pakchoi (Brassica chinensis L.). Commun Soil Sci Plant. 46 (13), 150611134844001, 2015.

6. KHATEEB W.A., AL-QWASEMEH H. Cadmium, copper and zinc toxicity effects on growth, proline content and genetic stability of Solanum nigrum L, a crop wild relative for tomato; comparative study. Physiol Mol Biol Plants. 20 (1), 31, 2014.

7. CHEN S., CHEN N., CHAO L., SUN J.J., SUN L., HAO X.X., LIU Q. The experimental study of polluted soils with oxytetracycline and cadmium by plant microbial remediation. Ecol Environ Sci. 24 (9), 1554, 2015.

8. DELEPEE R., POULIQUEN H., BRIS H.L. The bryophyte Fontinalis antipyretica Hedw. bioaccumulates oxytetracycline, flumequine and oxolinic acid in the freshwater environment. Sci Total Environ. 322 (1-3), 243, 2004.
9. SALTE R. Oxytertracycline residues in rainbow trout (Salmo gairdneri) fed a commercial medicated feed. Acta Vet Scand. 23 (1), 150, 1982.

10. CAI Y., HAN Y.Y., HE Z.Z. Determination of oxytertracycline, tetracycline, chlortetracycline residues in milk products by reversed-phase high performance liquid chromatography. Chem World. 47 (7), 398, 2006.

11. BOONSANER M., HAWKER D.W. Accumulation of Oxytetracycline and Norfloxacin from Saline Soil by Soybeans. Sci Total Environ. 408 (7), 1731, 2010.

12. LI, J., CUI S.Y., CAO H.Y., FAN L.B., SU Y.H. The absorption and accumulation ability of oxytetracycline in solution by three kinds of vegetables. [In China.] Food Industry. 38 (8), 141, 2017.

13. XU Q., BAO C., GU G., ZHANG M. Phytotoxicity and accumulation of oxytetracycline from soil in Chinese cabbage (Brassica chinensis var. chinensis) with different growing stages. Chinese Agr Sci Bull. 30 (28), 189, 2014.

14. XIAO M.Y., AN J., JI Z.H., CUI S., LI P. Toxic effects of six typical antibiotics on seed germination and physiological characteristics of chinese cabbage. Chinese J Ecol. 33 (10), 2775, 2014.

15. WAHIDA N.H., ANUAR A.R., FAUZIAH C.I., OSUMANU H.A. Response of Brassica rapa var. parachinensis grown on copper contaminated oxisol, inceptisol and histosol. Malaysian J Soil Sci. 17 (1), 99, 2013.

16. ZHANG Z.L., QU W.J. Direction of Plant Physiology Experiments. Beijing: Higher Education Press. 2005.

17. ZHANG Y.S., HUANG X., CHEN X.F. Experimental course of Plant Physiology. Beijing: Higher Education Press. 2009.

18. PROINOKE X.H. The Methods of Analysis of Biochemistry on Plants. Beijing: Science Press. 1981.

19. CARTER M.R., GREGORICH E.G. Soil sampling and methods of analysis (2nd Edition). Boca Raton: CRC Press. 225, 2007.

20. KALRA Y.P., MAYNARD D.G. Methods manual for forest soil and plant analysis. information report NOR-X-319. Alberta: Forestry Canada, Northwest Region, Northern Forestry Centre. 1991.

21. GB/T22259. Determination of oxytetracycline in feeds High performance liquid chromatography. The National Standards of China. 2014.

22. TIAN Z.Y., CAO W.Y., ZOU X.D. Study of effect of oxytetracycline residue on germination of typical plants. Chemical Fertilizer Industry. 43 (06), 82, 2016 [In China].

23. CUI X. Phytotoxicity of Oxytetracline to Lettuce and its Photolysis in Metal Ion Solutions. Ms diss., Dalian University of Technology. 2007.

24. SHAKYA K., CHETTRI M.K., SAWIDIS T. Impact of heavy metals (copper, zinc, and lead) on the chlorophyll content of some mosses. Arch Environ Contam Toxicol. 54 (3), 412, 2008.

25. MARTINS L.L., MOURATO M.P. Effect of excess copper on tomato plants: growth parameters, enzyme activities, chlorophyll, and mineral content. J Plant Nutr. 29 (12), 2179, 2006.

26. CHEN Y., WANG Z., SHEN Z., QU Z., YUAN Z., ZHOU S. Effects of oxytetracycline on growth and chlorophyll fluorescence in rape (Brassica campestris L). Pol J Environ Stud. 26 (3), 995, 2017.

27. XU Q., ZHANG M. Oxytetracycline uptake and growth of radish plants (Raphanus sativus L) in animal manureamended soils. Agr Sci Technol. 15 (7), 1229, 2014. 
28. YANG T., LIU G., LI Y., ZHU S., ZOU A., QI J., YANG Y. Rhizosphere microbial communities and organic acids secreted by aluminum-tolerant and aluminum-sensitive soybean in acid soil. Biol Fert Soils. 48 (1), 97, 2012.

29. COBAN H., ERTEKIN E., INCE O., TURKER G., INCE B. Degradation of oxytetracycline and its impacts on biogas-producing microbial community structure. Bioprocess Biosyst Eng. 39 (7),1051, 2016.

30. YANG Z., JIA S., ZHANG T., ZHOU N., DONG Y., YANG W., WANG Y. How heavy metals impact on flocculation of combined pollution of heavy metalsantibiotics: A comparative study. Sep Purif Technol. 149 (2015), 398, 2015.
31. BENEDETTI M.F., MILNE C.J., KINNIBURGH D.G., RIEMSDIJK W.H.V., KOOPAL L.K. Metal ion binding to humic substances: application of the non-ideal competitive adsorption model. Environ Sci Technol. 29 (2), 446, 1995.

32. TEMMINGHOFF E.M.J., VAN DER ZEE S.E.A.T.M., KEIZER M.G. The influence of ph on the desorption and speciation of copper in a sandy soil. Soil Sci. 158 (6), 398, 1994.

33. MCCARTHY J.F., ZACHARA J.M. Subsurface transport of contaminants. Environ Sci Technol. 23 (5), 496, 1989. 